University of Wollongong

Research Online

Faculty of Engineering - Papers (Archive)

Faculty of Engineering and Information

Sciences

$1-1-2012$

\title{
Understanding the behavior of advanced high-strength steels using atom probe tomography
}

\author{
E V. Pereloma \\ University of Wollongong, elenap@uow.edu.au \\ Hossein Beladi \\ Deakin University \\ Laichang Zhang \\ University of Western Australia, laichang@uow.edu.au \\ Ilana Timokhina \\ Deakin University, Ilana.Timokhina@eng.monash.edu.au
}

Follow this and additional works at: https://ro.uow.edu.au/engpapers

https://ro.uow.edu.au/engpapers/5114

\section{Recommended Citation}

Pereloma, E V.; Beladi, Hossein; Zhang, Laichang; and Timokhina, llana: Understanding the behavior of advanced high-strength steels using atom probe tomography 2012, 3958-3971.

https://ro.uow.edu.au/engpapers/5114

Research Online is the open access institutional repository for the University of Wollongong. For further information contact the UOW Library: research-pubs@uow.edu.au 


\title{
Understanding the Behavior of Advanced High-Strength Steels Using Atom Probe Tomography
}

\author{
ELENA PERELOMA, HOSSEIN BELADI, LAICHANG ZHANG, \\ and ILANA TIMOKHINA
}

\begin{abstract}
The key evidence for understanding the mechanical behavior of advanced high strength steels was provided by atom probe tomography (APT). Chemical overstabilization of retained austenite (RA) leading to the limited transformation-induced plasticity (TRIP) effect was deemed to be the main factor responsible for the low ductility of nanostructured bainitic steel. Appearance of the yield point on the stress-strain curve of prestrained and bake-hardened transformationinduced plasticity steel is due to the unlocking from weak carbon atmospheres of newly formed during prestraining dislocations.
\end{abstract}

DOI: $10.1007 / \mathrm{s} 11661-011-0782-0$

(C) The Minerals, Metals \& Materials Society and ASM International 2011

\section{INTRODUCTION}

THE current trend in the design of new cost-effective steels is aimed to tailor the specific properties toward their applications and, by this, to attain the enhanced performance in service. However, to achieve this, an indepth understanding of the role of alloying additions during various stages of steel manufacturing and service life is required. Atom probe tomography ${ }^{[1-3]}$ (APT) is a technique that is very well suited for this task. It allows three-dimensional characterization at the atomic level of elemental partitioning between phases present in the complex microstructures of steels ${ }^{[-10]}$ and segregation of solute to the boundaries, interfaces, twins, and dislocations, ${ }^{[8,10-16]}$ as well as following of the evolution of precipitation starting from the early stage of cluster formation to the final stage of the equilibrium precipitates. ${ }^{[15-23]}$

In this work, we use as examples the application of APT to two classes of steels: nanostructured bainitic and transformation-induced plasticity (TRIP) steels. The former ones were first developed by the group of Professor Bhadeshia, Cambridge University, ${ }^{[6,24,25]}$ for applications in defense and construction, which are required to possess extremely high strength and toughness. These steels showed strength of $\sim 2.5 \mathrm{GPa}$ and toughness of 30 to $40 \mathrm{MPa} \mathrm{m}{ }^{1 / 2}$. These properties were

ELENA PERELOMA, Professor of Physical Metallurgy and Director of BlueScope Steel Metallurgy Centre, Faculty of Engineering, is with the School of Mechanical, Materials and Mechatronic Engineering, University of Wollongong, NSW 2522, Australia. Contact e-mail: elenap@uow.edu.au HOSSEIN BELADI, Senior Research Academic, and ILANA TIMOKHINA, Senior Research Academic, are with the Centre for Material and Fibre Innovation, Deakin University, Geelong, VIC 3217, Australia. LAICHANG ZHANG, Research Assistant Professor, formerly with the School of Mechanical, Materials and Mechatronic Engineering, University of Wollongong, is now with the Department of Mechanical Engineering, University of Western Australia, Crawley, WA, Australia.

Manuscript submitted March 31, 2011.

Article published online September 17, 2011 associated with the formation of 20- to 40-nm-thick nanoscale bainitic ferrite (BF) plates with fine interlayers of the retained austenite (RA) in the microstructure of these steels due to incomplete bainite transformation in the presence of high silicon content. APT was successfully used to study solute redistribution in these steels. ${ }^{[8,9,18,26]}$ However, to achieve this microstructure, heat treatment for 24 to 48 hours or longer is required, which makes these steels economically unviable for many applications outside the heavy section products. In addition, high $\mathrm{C}$ content poses a significant problem for welding of this steel. Thus, efforts were made to modify both the composition and processing schedules of this class of steels, especially with the introduction of deformation prior to isothermal heat treatment in order to accelerate the austenite to $\mathrm{BF}$ transformation. [24] Another approach to lower the alloying element content but maintain a good combination of strength and toughness is to consider, similarly to the standard TRIP steels, a multiphase steel with optimized stability of RA. It is well documented that the realization of the TRIP effect depends on a combination of various microstructural characteristics, such as (1) the volume fraction of the RA; (2) the morphology and size/thickness of the RA crystals; (3) the carbon content of the RA; (4) the location of the RA, if dealing with multiphase steel; and (5) the dislocation density of the BF. ${ }^{[27,28]}$ The lowering of carbon content in the steel composition could be partially compensated by the formation of low-carbon polygonal ferrite and careful control of morphology and distribution of phases in the microstructure. ${ }^{[29]}$ The effectiveness of this approach, in particular, will also be evaluated in this work.

When the steels are used for automotive body parts, they are subjected to the paint baking cycle at temperatures $423 \mathrm{~K}$ to $473 \mathrm{~K}\left(150{ }^{\circ} \mathrm{C}\right.$ to $\left.200{ }^{\circ} \mathrm{C}\right)$ for 20 to 30 minutes, resulting in an additional increment in yield strength of approximately 100 to $200 \mathrm{MPa} \cdot{ }^{[30-34]}$ This is an important contribution to in-service properties, such as a low springback and improved dent and crash resistance. ${ }^{[32]}$ Extensive investigations have established 
the mechanisms and stages of the bake hardening behavior of low carbon steels, which are controlled by the amount of interstitial carbon atoms and the formation of Cottrell atmosphere and precipitations. ${ }^{[35,36]}$ Compared with the low carbon steels, the bake hardening behavior in TRIP steels is expected to be more complex in nature due to their complex multiphase microstructure. Limited data showed that the bake hardening behavior of the TRIP steels depend on the processing methods and on the phase morphologies/ fractions resulting from their chemical compositions. ${ }^{[34,37-39]}$ It was proposed that the bake hardening behavior is associated with the changes of the dislocation substructure in the polygonal ferrite matrix. ${ }^{[30-34,37,38]}$ However, the information on the bake hardening mechanism for the TRIP steels having a predominantly bainite matrix with a high dislocation density rather than a polygonal ferrite one is limited. ${ }^{[39]}$ Therefore, in-depth studies of solute segregation resulting from the prestrain and bake hardening (PS/BH) treatment of such TRIP steels are warranted.

This article consists of two parts: the first one addresses design and mechanical behavior of nanoscale bainitic steels, whereas the second focuses on the explanation of the influence of bake hardening on the mechanical properties in TRIP steel with predominantly bainitic microstructure. In both cases, application of APT played a critical role in finding the answers to the raised questions. Specifically, APT results explain the improvement in work hardening behavior in lower carbon Mo-alloyed nanobainitic steel compared to the standard high carbon nanobainitic steel, as well as name a weak carbon segregation to newly formed during prestraining dislocations as the main reason for appearance of the yield point on stress-strain curves of the TRIP steel after bake hardening.

\section{EXPERIMENTAL}

The compositions of three steels used in the present work are given in Table I. The nanostructured steel 1 was reheated to $1423 \mathrm{~K}\left(1150{ }^{\circ} \mathrm{C}\right)$ for 30 minutes, then isothermally heat treated at $523 \mathrm{~K}\left(250{ }^{\circ} \mathrm{C}\right)$ for 5 days (7200 minutes) to form nanoscale bainite, and quenched. On the other hand, the nanostructured multiphase steel 2 after reheating to $1273 \mathrm{~K}\left(1000{ }^{\circ} \mathrm{C}\right)$ was subjected to a more complex schedule in order to form polygonal ferrite during the isothermal hold at $923 \mathrm{~K}\left(650^{\circ} \mathrm{C}\right)$ for 210 minutes and then nanoscale bainite at $573 \mathrm{~K}$ $\left(300{ }^{\circ} \mathrm{C}\right.$ ) during 120 minutes hold followed by quenching. TRIP steel 3 was produced by a standard cold rolling and intercritical annealing processing. To study the effect of the PS/BH treatment on the mechanical properties, tensile specimens were machined from the steel 3 strip and subjected to 4 pct prestraining in tension before bake hardening at $453 \mathrm{~K}\left(180{ }^{\circ} \mathrm{C}\right)$ for 30 minutes.

An INSTRON* 4500 servohydraulic tensile testing

*INSTRON is a trademark of Illinois Tool Works Inc., Canton, MA.

machine with a $100-\mathrm{kN}$ load cell and crosshead speed of $0.5 \mathrm{~mm} / \mathrm{min}$ was used to measure the mechanical properties of the steels at room temperature. A series of up to three tests were used to define the average values of mechanical properties. The yield strength was defined by the 0.2 pct offset stress $\left(\sigma_{0.2}\right)$ method. The strain during tensile testing was measured by extensometer. The bake hardening response was measured as the strength difference between the upper yield strength after $\mathrm{PS} / \mathrm{BH}$ treatment and the strength value after 4 pct prestraining. ${ }^{[36]}$

X-ray diffraction analysis was performed using a Rigaku D/max 2400 diffractometer (Rigaku Corp., Tokyo, Japan) (40 kV, $25 \mathrm{~mA})$ equipped with a monochromator using $\mathrm{Cu} K_{\alpha}$ radiation to confirm the amount of RA in the microstructure. Spectra were taken in the range from 30 to $120 \mathrm{deg}$ with a $0.02-\mathrm{deg}$ step size. The integrated intensities of the $(200)_{\alpha},(211)_{\alpha},(200)_{\gamma}$, and (220), peaks were used in the direct comparison method. ${ }^{[40]}$ The carbon concentration of the RA was calculated from the lattice constant measured from the (200) $\gamma$ and (220) diffraction peaks and using the following equation: ${ }^{[41]}$

$$
\begin{aligned}
a_{\gamma}= & (0.363067+0.0783 /(1+0.2151(100 / \text { wt pctC }-1))) \\
& \times(1+(24.92-51 /(1+0.2151(100 / \text { wt pct } \mathrm{C}-1))) \\
& \times 10^{-6}(T-727)
\end{aligned}
$$

The microstructure was characterized using optical metallography, transmission electron microscopy (TEM), and APT. The samples for TEM and atom probe studies were cut perpendicular to the deformation (rolling) direction. Thin foils for TEM were prepared by twin jet electropolishing using a solution of 5 pct perchloric acid in methanol at $253 \mathrm{~K}\left(-20{ }^{\circ} \mathrm{C}\right)$ and an

\begin{tabular}{|c|c|c|c|c|c|c|c|c|c|c|c|}
\hline Steel & & $\mathrm{C}$ & $\mathrm{Mn}$ & $\mathrm{Si}$ & $\mathrm{Al}$ & $\mathrm{Co}$ & $\mathrm{Cr}$ & Mo & $\mathrm{Cu}$ & $\mathrm{Ni}$ & $\mathrm{P}$ \\
\hline \multirow[t]{2}{*}{ Steel 1 Nanobainite } & wt pct & 0.79 & 1.98 & 1.51 & 1.06 & 1.58 & 0.98 & 0.24 & 0.1 & 0.1 & - \\
\hline & at. pct & 3.48 & 1.9 & 2.85 & 2.08 & 1.42 & 1.0 & 0.13 & 0.09 & 0.08 & - \\
\hline \multirow[t]{2}{*}{ Steel 2 Mo steel } & wt pct & 0.3 & 2 & 1.96 & - & - & 0.1 & 0.31 & 0.01 & 0.01 & - \\
\hline & at. pet & 1.2 & 1.9 & 3.8 & - & - & 0.1 & 0.17 & 0.01 & 0.01 & - \\
\hline \multirow[t]{2}{*}{ Steel 3 TRIP steel } & wt pct & 0.21 & 1.64 & 1.38 & 0.04 & - & 0.03 & 0.01 & 0.01 & - & 0.2 \\
\hline & at. pct & 0.95 & 1.62 & 2.68 & 0.089 & - & - & 0.005 & 0.009 & - & - \\
\hline
\end{tabular}
operating voltage of $50 \mathrm{~V}$. Bright-field and dark-field

Table I. Chemical Compositions of Studied Steels 
images and selected area electron diffraction patterns were obtained using PHILIPS CM 20**, operated at

** PHILIPS is a trademark of FEI Company, Hillsboro, OR.

$200 \mathrm{kV}$. The dislocation density of the BF was calculated using the intersection method:

$$
\Lambda=2 N_{L} / L t
$$

where $N_{L}$ is the number of intersections with dislocations, $L$ is the length of random lines, and $t$ is the foil thickness. The two-beam convergent beam electron diffraction (CBED) method was used to determine the foil thickness $(t)$. The thickness of the BF and RA layers was measured by the intersection method using five bright TEM images at a magnification of 38,000 times.

A standard two-stage electropolishing procedure ${ }^{[2]}$ was used to prepare the needle-shaped atom probe samples using 33 pct nitric acid in methanol for the first stage, followed by 2 pct perchloric acid in butoxyethanol at $16 \mathrm{~V}$. APT on steels 1 and 2 was conducted using the Oxford nanoScience 3DAP (Oxford nanoScience Ltd., Milton Keynes, UK) at the Monash Centre for Electron Microscopy. The pulse repetition rate was $20 \mathrm{kHz}$, the pulse fraction was 0.2 , and the sample temperature was $60 \mathrm{~K}\left(-213{ }^{\circ} \mathrm{C}\right)$. Atom probe experiments on steel 3 were performed on a local electrode atom probe $\left(\mathrm{LEAP}^{\dagger}\right)$ located at the University of

${ }^{\dagger}$ LEAP is a trademark of CAMECA, Gennevilliers, France.

Sydney, with a sample temperature of $80 \mathrm{~K}\left(-193{ }^{\circ} \mathrm{C}\right)$, a pulse repetition rate of $200 \mathrm{kHz}$, and a pulse fraction of 0.2. The composition of various phases was obtained from the volumes of interest free from any visible element segregation (e.g., clusters, precipitates, Cottrell atmospheres, and boundaries) based on the number of atoms present after background noise was subtracted.

The maximum separation envelope method ${ }^{18}$ with $d_{\max }=1 \mathrm{~nm}$ was used to identify carbon segregation to dislocations, clusters, and fine precipitates in polygonal ferrite or BF. A minimum of 20 atoms was used for the small clusters to eliminate random fluctuations. The Guinier radii, $r_{\mathrm{G}}$, of clusters/fine carbides were calculated from radii of gyration $\left(l_{g}\right)$ data with the equation $r_{\mathrm{G}}=\sqrt{ }(5 / 3) l_{g}{ }^{[2]}$ Iso-concentration surfaces were also used for better visualization of features of interest.

\section{RESULTS AND DISCUSSION}

\section{A. Nanostructured Bainitic Steels}

\section{Mechanical properties}

Steel 1 has shown high strength ( 1900 MPa), but relatively poor ductility (Table I). This was the main reason for the design of steel 2. Reduction in carbon content was expected to be partially offset by increased Mo content in order to maintain a reasonable strength level. At the same time, formation of the polygonal ferrite in the microstructure should have a positive effect on ductility. This approach was based on our previous experience in the design of thermomechanical schedules for TRIP steels, ${ }^{[7]}$ where an excellent strength-ductility balance was achieved. As could be seen from Table II, the strength and ductility balance improved in steel 2 compared to that in steel 1 . The still relatively high ultimate tensile strength of $\sim 1300 \mathrm{MPa}$ was accompanied by an increase in the total elongation from 8 pct in steel 1 to 13 pct in steel 2. In addition, work hardening was also improved. The hardness measurements followed the expected trend: $\mathrm{Hv}_{20 \mathrm{~kg}}=579 \pm 6$ for steel 1 and $\mathrm{Hv}_{20 \mathrm{~kg}}=415 \pm 4$ for steel 2. In order to gain an understanding of the obtained properties, detailed microand nanoscale analyses of both steels were carried out.

\section{Microstructure characterization}

Optical micrographs show a fully bainitic microstructure in steel 1 (Figure 1(a)), whereas in steel 2, approximately 20 pct of polygonal ferrite (PF) was also present (Figure 1(b)). PF grains formed at prior austenite boundaries and their sizes were within the 4- to $15-\mu \mathrm{m}$ range. The volume fractions of RA before and after tensile testing were $20 \pm 2$ pct and $9 \pm 1$ pct for steel 1 , and $14 \pm 2$ pct and $5 \pm 1$ pct for steel 2, respectively. Before tensile testing, the average carbon content in the RA calculated based on XRD data was 7.5 at. pct (1.7 wt pct) for steel 1 and 4 at. pct $(0.91 \mathrm{wt}$ pct) for steel 2.

Formation of BF colonies in both steels is clearly visible in Figures 2(a) and 3(a). Parallel arrangements of $\mathrm{BF}$ laths with low-angle boundaries were in each colony. The microstructure was finer in steel 1 compared to steel 2, with corresponding thicknesses of $\mathrm{BF}$ laths of $\sim 0.16 \pm 0.08 \mu \mathrm{m}$ and $\sim 0.3 \pm 0.1 \mu \mathrm{m}$. The dislocation density in BF laths was of the same order of magnitude in both steels $\left(\sim 2\right.$ to $\left.3 \times 10^{15} \mathrm{~m}^{-2}\right)$. Fine thin films of RA were observed between parallel laths of $\mathrm{BF}$ having an average thickness of $0.03 \pm 0.01$ and $0.1 \pm 0.06 \mu \mathrm{m}$

Table II. Mechanical Properties of the Steels

\begin{tabular}{lrrrrrr}
\hline \multicolumn{1}{c}{ Steels } & & & & & \\
\hline & & $\sigma_{\text {UTS }}(\mathrm{MPa})$ & $\sigma_{\mathrm{y}}(\mathrm{MPa})$ & $\varepsilon_{\text {total }}(\mathrm{Pct})$ & $\varepsilon_{\mathrm{u}}(\mathrm{Pct})$ & BHR $(\mathrm{MPa})$ \\
\hline Steel 1 & & $1900 \pm 20$ & $1600 \pm 20$ & $8 \pm 1$ & $7 \pm 1$ & - \\
Steel 2 & & $1300 \pm 20$ & $900 \pm 15$ & $13 \pm 3$ & $7.5 \pm 1$ & - \\
Steel 3 & as received & $880 \pm 15$ & $608 \pm 20$ & $40 \pm 2$ & $30 \pm 2$ & $82 \pm 2$ \\
& 4 pct PS/BH & $891 \pm 15$ & $803 \pm 20$ & $29 \pm 2$ & $21 \pm 2$ & 8 \\
\hline
\end{tabular}

$\sigma_{\mathrm{UTS}}:$ ultimate tensile strength, $\sigma_{y}$ : yield strength, $\varepsilon_{\text {total }}$ : total elongation, $\varepsilon_{u}$ : uniform elongation, and BHR: bake hardening response. 

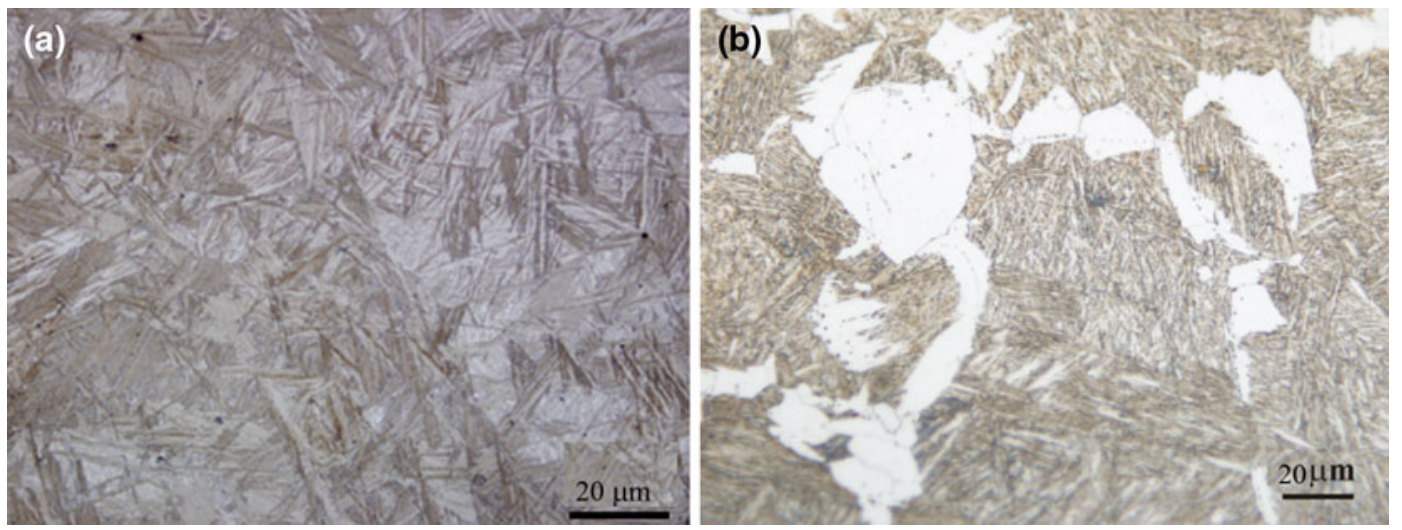

Fig. 1-Optical micrographs of $(a)$ steel 1 and $(b)$ steel 2.
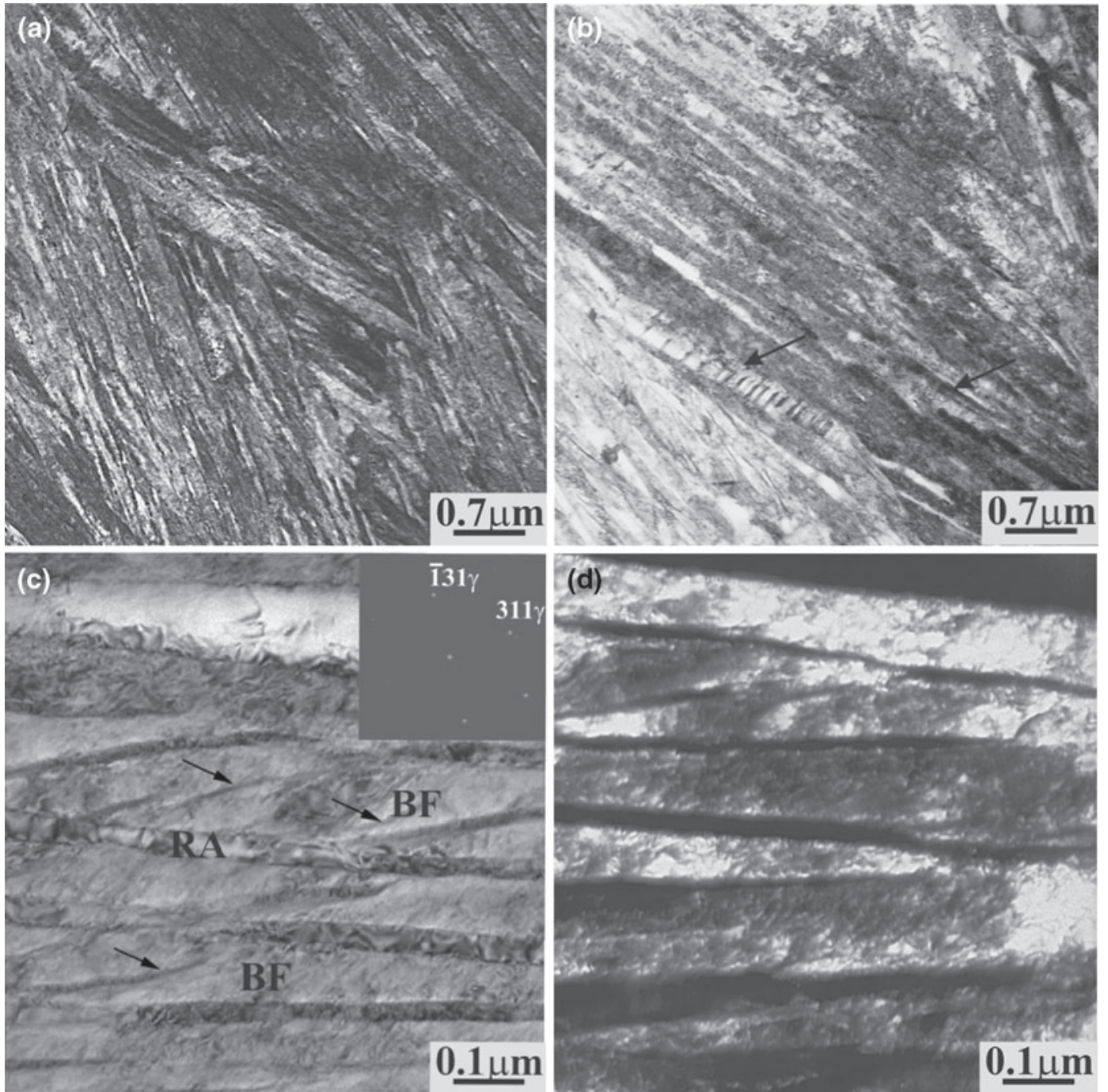

Fig. 2-TEM microstructures of steel 1: showing $(a)$ general view and $(b)$ twinned RA indicated by arrows, $(c)$ bright-field, and (d) dark-field images of the lamella bainitic structure. Arrows in (c) indicate fine RA crystals oriented under $\sim 30$ deg to the main RA layers. The zone axis is [125], in inset, RA is retained austenite, and $\mathrm{BF}$ is bainitic ferrite.

in steels 1 and 2, respectively (Figures 2(c), 2(d), 3(c), and 3(d)). However, these RA layers were slightly coarser than the lenticular RA crystals inclined under $\sim 30 \mathrm{deg}$ to them (Figures 2(c), (d), and 3(b)). The latter ones were only $0.02-$ to $0.05-\mu \mathrm{m}$ thick. In addition, some relatively thick RA layers were twinned in steel 1 

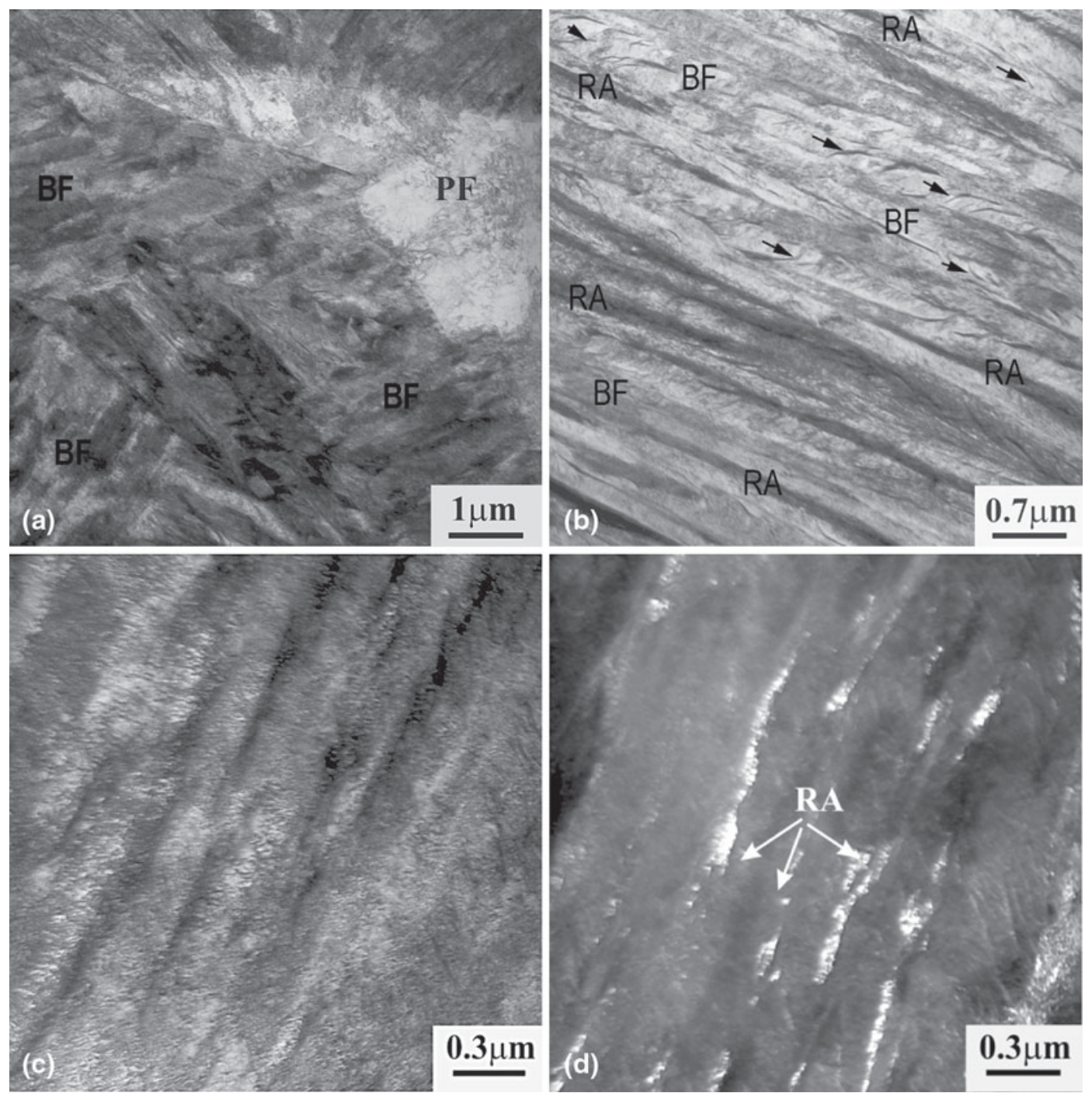

Fig. 3-TEM micrographs of steel 2: (a) general view of BF packets and polygonal ferrite (PF); $(b)$ subunits of parallel BF laths with low-angle boundary orientations and RA layers, inclined to the main RA layers by about 30 deg and indicated by the arrows; and $(c)$ bright-field and $(d)$ dark-field images showing the BF laths with thin RA films.

(Figure 2(b)). The observed differences in microstructure coarseness are associated with the different temperatures of isothermal heat treatment in these steels and their compositions. For steel 1 , at lower temperature of $523 \mathrm{~K}\left(250^{\circ} \mathrm{C}\right)$, there is not only a larger driving force for nucleation of $\mathrm{BF}$, but the formation of $\mathrm{BF}$ is also restricted much earlier due to supersaturation of the surrounding austenite with carbon diffusing out of the $\mathrm{BF}$. Each subsequently formed BF lath grows in carbonenriched austenite from the previous BF lath formation. The driving force for displacive $\mathrm{BF}$ formation reduces with the increase in the carbon content in austenite. According to the incomplete bainite transformation phenomenon, the reaction ceases before austenite reaches it paraequilibrium composition. ${ }^{[42,43]}$ Thus, in the steel with higher carbon content, the attainment of the condition with zero driving force for transformation will be earlier than in the steel with much lower carbon content. However, the fraction transformed increases with lowered transformation temperature. Thus, two competing factors (temperatures of transformation $523 \mathrm{~K}$ vs $573 \mathrm{~K}\left(250{ }^{\circ} \mathrm{C}\right.$ vs $\left.300{ }^{\circ} \mathrm{C}\right)$ and carbon content of the steels $(0.8$ vs $0.3 \mathrm{wt}$ pct) $)$ defined the small difference in the amount of the RA formed in each steel: $\sim 20$ pct in steel 1 and 14 pct in steel 2 .

\section{Atom probe analysis}

A representative carbon atom map of steel 1 is shown in Figure 4(a). The volumes of high and low carbon concentrations are clearly visible, which, based on compositional analysis, were identified as BF and RA with compositions given in Table III. Both atom map and iso-concentration surfaces (Figure 4(b)) also highlighted the presence of plate-like carbides in the BF. The concentration profiles across the $\mathrm{BF} / \mathrm{RA}$ interface also showed the difference in $\mathrm{C}$ content between the phases, whereas the concentrations of substitutional elements were, within experimental error, the same in both phases (Figures 4(c) through (h)). The spike in $\mathrm{Si}$ at the interface was of the same magnitude as the ones present 


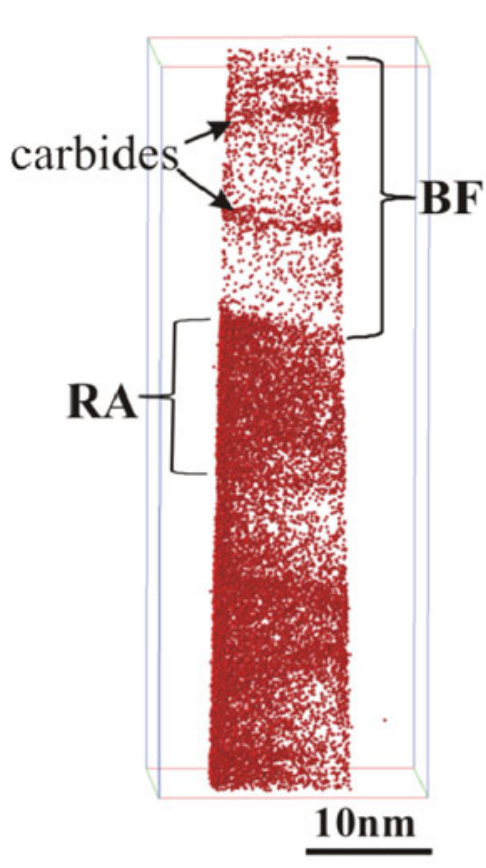

(a)

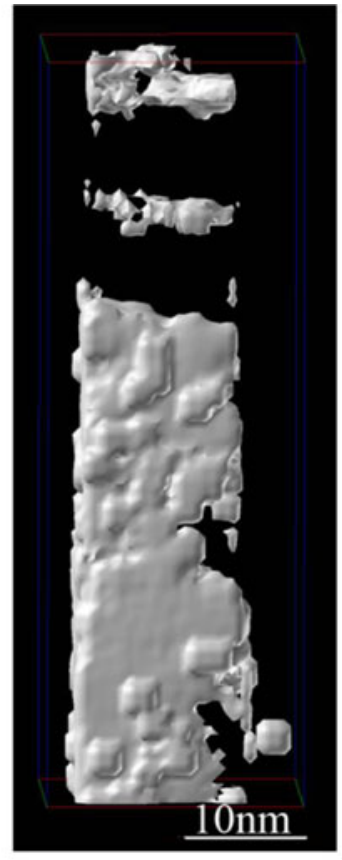

(b)

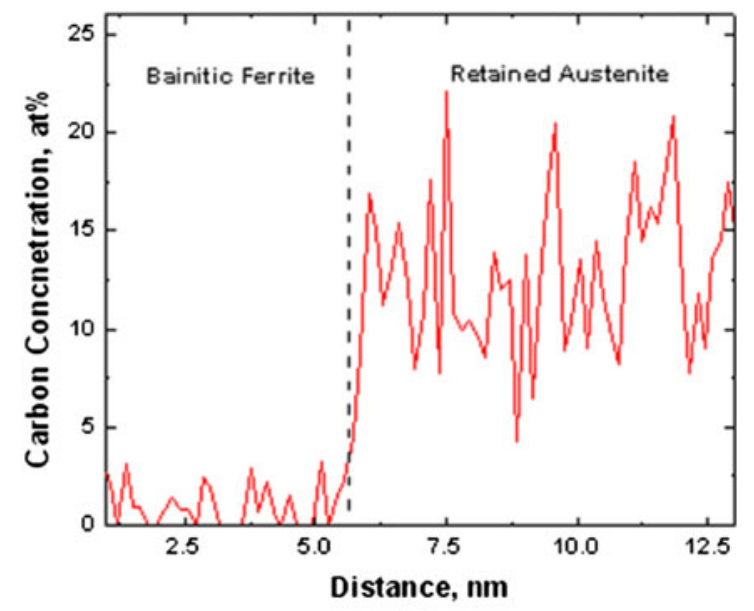

(c)

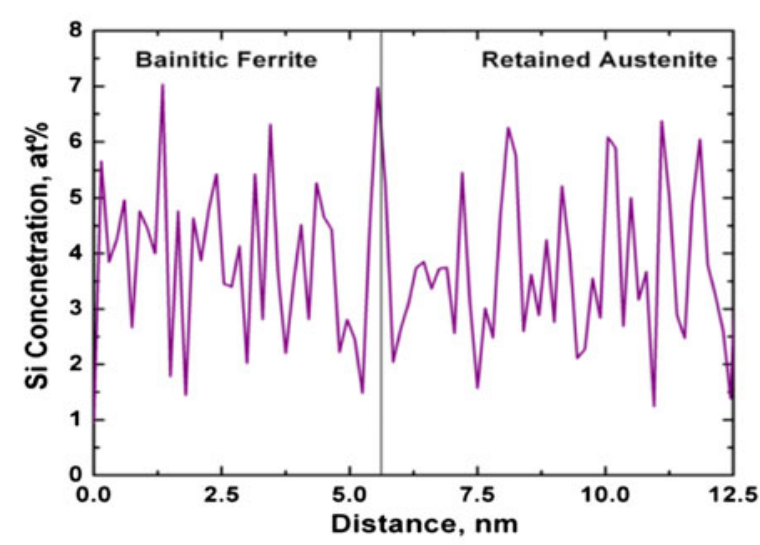

(d)

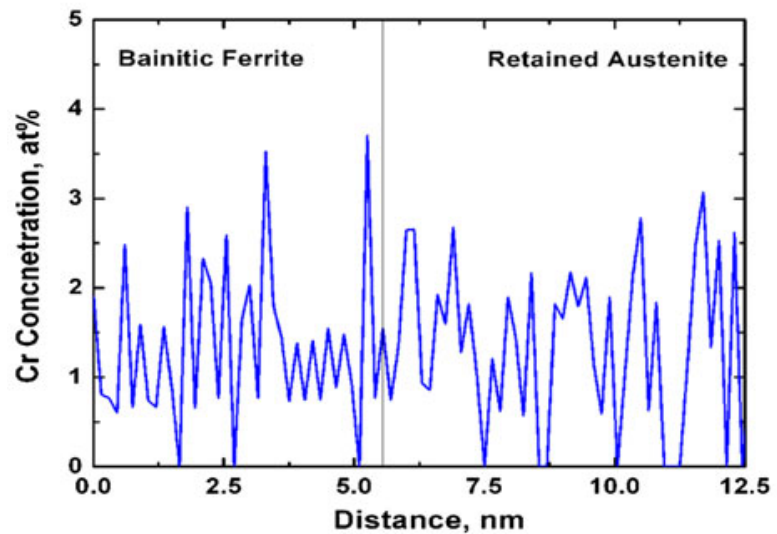

(f)

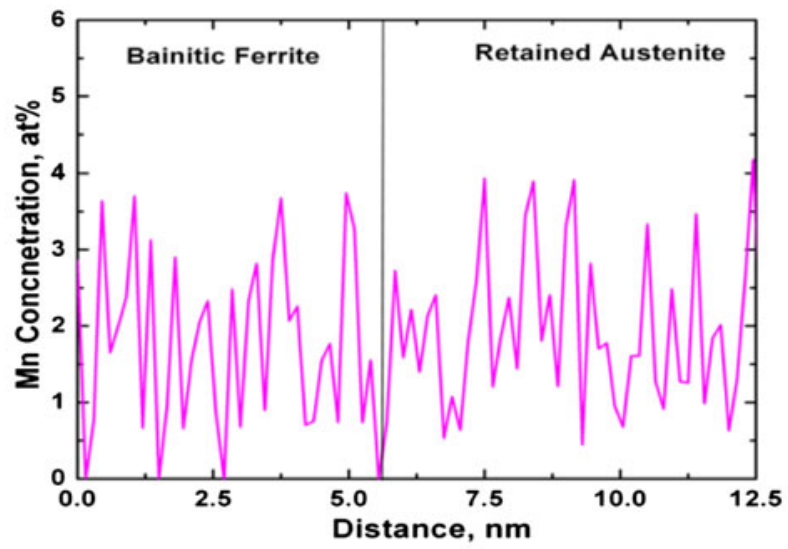

(e)

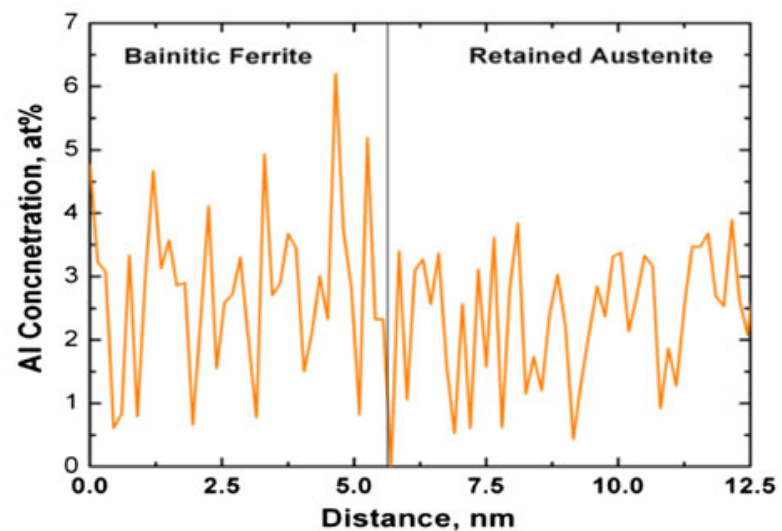

(g)

Fig. 4-Atom probe analysis of steel 1: (a) C atom map, (b) 3 at. pct C iso-concentration surfaces, and (c) through ( $g$ ) concentration profiles across the $\mathrm{BF} / \mathrm{RA}$ interface. 


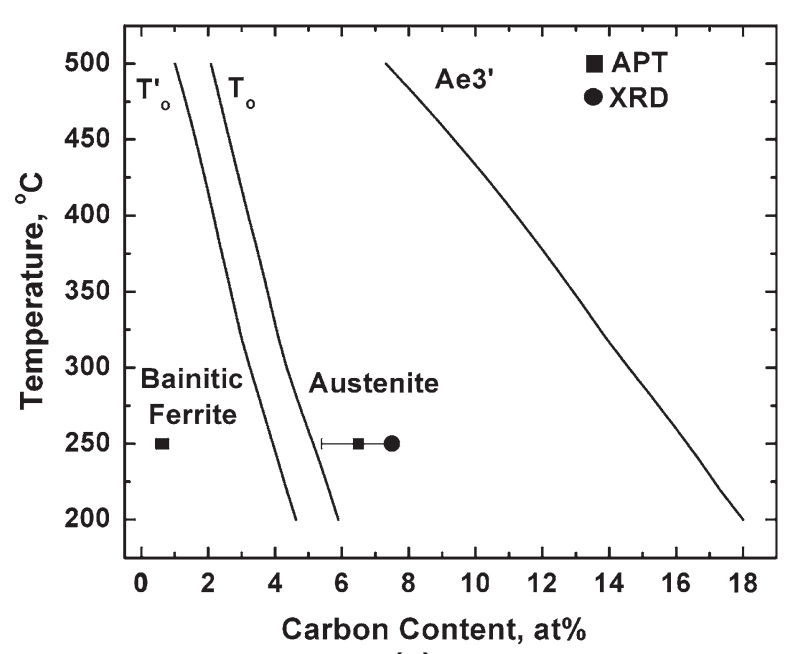

(a)

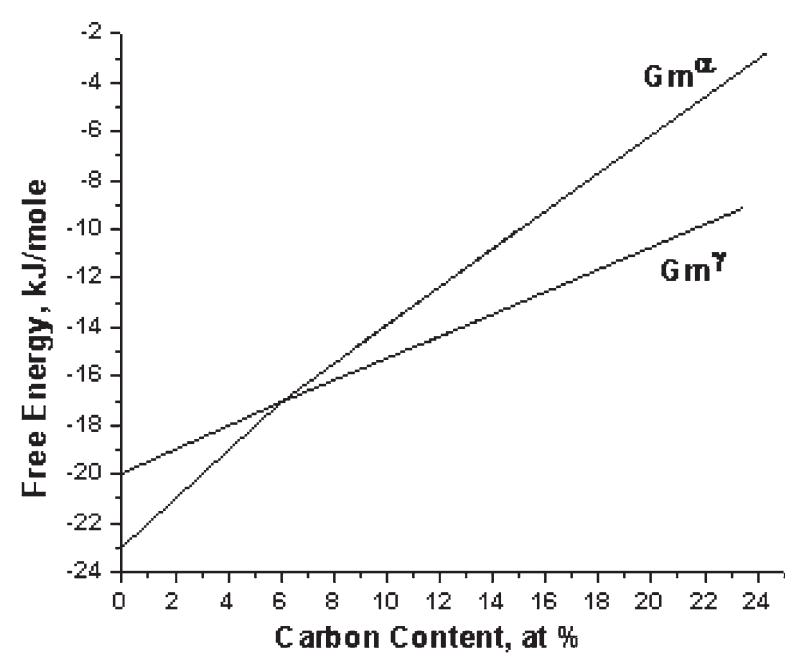

(b)

Fig. 5- (a) Comparison of atom probe data with the calculated paraequilibrium phase diagram for the nanobainitic steel 1 and (b) calculated variation of molar Gibbs free energy of austenite and ferrite for the same steel at $523 \mathrm{~K}\left(250^{\circ} \mathrm{C}\right)$.

within the BF. Thus, it could be concluded that no unambiguous segregation of solute was visible at the $\mathrm{BF} / \mathrm{RA}$ interface.

These data are in agreement with previously reported APT results on the absence of substitutional element diffusion during $\mathrm{BF}$ formation ${ }^{[6,7,44]}$ and support the displacive mechanism of incomplete bainite transformation. The calculated and measured carbon contents in the $\mathrm{BF}$ are compared in Figure 5(a). The measured values for carbon content in $\mathrm{BF}$ and $\mathrm{RA}$ were obtained from several APT runs from the areas of interest, and their average values with standard deviation are shown in Figure 5(a). The calculations of $T_{o}$ and $T_{o}^{\prime}$ were carried out using MAP freeware. ${ }^{[45,46]}$ The measured carbon content in $\mathrm{BF}$ is significantly higher than that for the para-equilibrium condition, but lower than $T_{o}^{\prime}$. It is worth mentioning that the composition of phases was determined in the volumes free of visible carbon segregation, such as clusters, atmospheres at dislocations, and boundaries. Thus, the remaining supersaturation in carbon compared to the paraequilibrium value could not be explained, as proposed previously by Stark et al., ${ }^{[47]}$ by the trapping of carbon at dislocations. However, it could be considered that trapping still takes place, but the levels of carbon at dislocations are much lower than those of Cottrell atmospheres and, thus, are not identifiable by APT. The carbon content in austenite is higher than $T_{o}$, but below its para-equilibrium phase boundary value $\left(A e_{3}^{\prime}\right)$. A significant variation in the determined values is associated with non-uniform carbon enrichment of austenite crystals due to their location and time of formation, as it was mentioned previously the RA continues to be enriched in carbon due to its rejection from supersaturated BF. These above $T_{o}$ values also indicate the incomplete bainite transformation phenomenon, as bainite formation could not take place when carbon content in austenite exceeds $T_{o}$ due to the absence of the required thermodynamic conditions. The carbon content in the RA obtained by $\mathrm{XRD}$ is at the upper boundary for the range of the carbon concentrations determined by atom probe. This is due to the XRD data accounting for the total carbon content in the RA, including segregations at dislocations and grain boundaries, whereas atom probe data were obtained for the volumes free of any visible carbon segregations. The calculations using THERMO-CALC software (Thermo-Calc Software, Stockholm) ${ }^{[48]}$ and the Thermo-Tech Iron database ${ }^{[49]}$ also showed that the measured average value of carbon content in the RA is higher than that predicted at $523 \mathrm{~K}\left(250{ }^{\circ} \mathrm{C}\right)$ for equilibrium conditions (Figure 5(b)).

APT examination of steel 2 (Figure 6) has allowed analysis of all three phases present, e.g., PF, BF, and RA. The determination of carbon content in each phase was performed again only in the volumes of uniform carbon distribution and resulted in $0.03 \pm 0.003$ at. pct in $\mathrm{PF}, 0.4 \pm 0.08$ at. pet in $\mathrm{BF}$, and $3.04 \pm 0.03$ at. pet in RA. The carbon content in the PF was in agreement with the para-equilibrium phase diagram and diffusioncontrolled mechanism of its formation. BF is also supersaturated with carbon, but slightly to a lesser extent than that in steel 1 , probably due to the overall lower carbon content in steel 2 and also the higher transformation temperature, which accelerates carbon diffusion out from the BF during its growth. Enrichment of the RA with carbon was also significantly less than in steel 1. Although the initial formation of the PF accompanied by the diffusion of carbon back into untransformed austenite partially compensated for the lower carbon content in steel 2, carbon concentration in the RA remained much lower than that in steel 1 (Table III). It is also of interest that a significant segregation of carbon in the form of the partially interconnected network was observed within the RA, as seen in the 7.5 at. pct $\mathrm{C}$ iso-concentration surfaces (Figure 6(e)).

In both steels in the $\mathrm{BF}$, the formation of $\mathrm{C}$-rich clusters with $90 \pm 5$ at. pct, $\mathrm{FeC}_{8}$ carbides, $\mathrm{Fe}_{2.4} \mathrm{C}$, and other transition iron carbides with carbon content varied from 40 to 60 at. pet was observed. In general, 


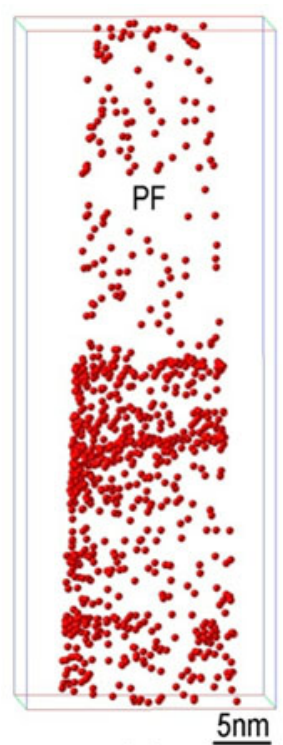

(a)

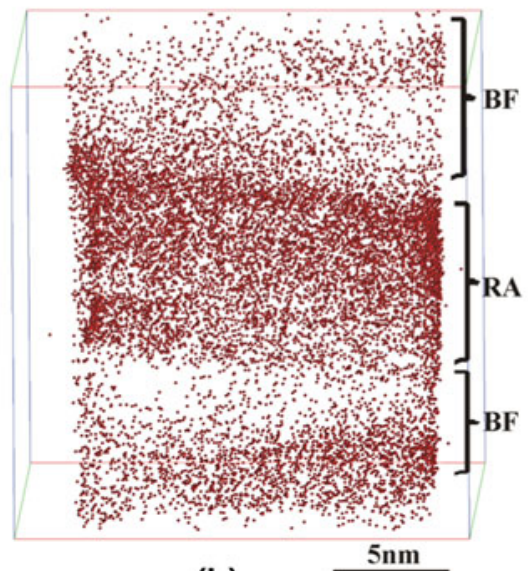

(b)

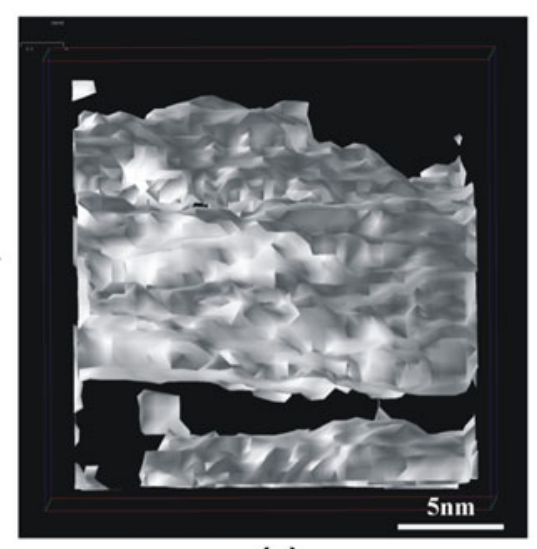

(c)

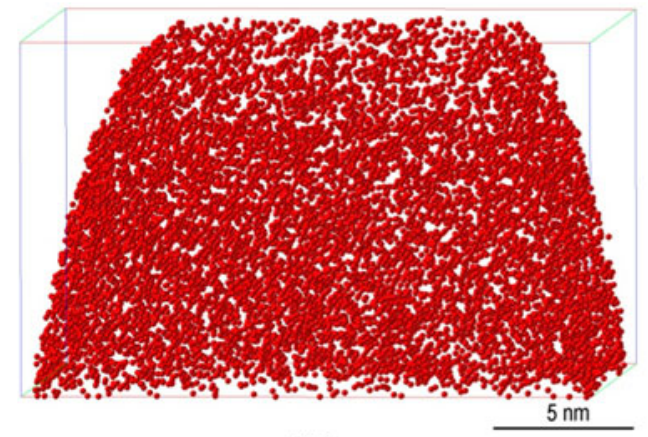

(d)

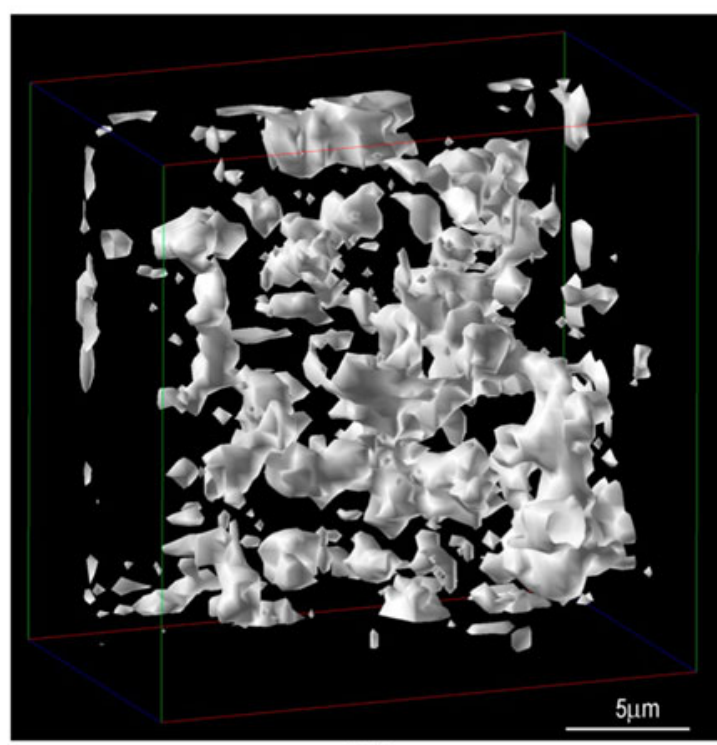

(e)

Fig. 6-Atom probe analysis of steel 2: (a) C carbon map of polygonal ferrite (PF), (b) C carbon map of carbide-free bainite and (c) corresponding 3 at. pet $\mathrm{C}$ iso-concentration surfaces, $(d) \mathrm{C}$ carbon map of RA, and $(e)$ corresponding 7.5 at. pct iso-concentration surfaces.

Table III. Composition of Phases in Nanostructured Bainite Steel 1 Determined Using APT (At. Pct)

\begin{tabular}{lccccccccc}
\hline Phase & $\mathrm{C}$ & $\mathrm{Mn}$ & $\mathrm{Si}$ & $\mathrm{Al}$ & $\mathrm{Co}$ & $\mathrm{Cr}$ & $\mathrm{Mo}$ & $\mathrm{Cu}$ & $\mathrm{Ni}$ \\
\hline $\mathrm{BF}$ & $0.56 \pm 0.09$ & $1.71 \pm 0.06$ & $3.88 \pm 0.08$ & $2.8 \pm 0.09$ & $1.75 \pm 0.06$ & $1.12 \pm 0.06$ & $0.09 \pm 0.02$ & $0.04 \pm 0.008$ & $0.06 \pm 0.02$ \\
$\mathrm{RA}$ & $6.45 \pm 0.8$ & $1.87 \pm 0.07$ & $3.85 \pm 0.18$ & $2.63 \pm 0.07$ & $1.78 \pm 0.09$ & $1.21 \pm 0.06$ & $0.10 \pm 0.01$ & - & $0.01 \pm 0.004$ \\
\hline
\end{tabular}

the estimated carbon level in the clusters/fine precipitates is overestimated by the maximum separation envelope method (by 25 to 40 pct) due to the aggressive removal from the surface of iron atoms. This is especially significant for the finest clusters with $r_{\mathrm{G}} \sim 1$ to $2 \mathrm{~nm}$, which have a high proportion of surface to volume atoms. ${ }^{[21]}$ However, as has been recently shown by neutron diffraction studies and ab initio calculations, the composition of cementite continuously varies with temperature having $\mathrm{Fe}_{3} \mathrm{C}_{x}$ composition due to low energy for carbon vacancies formation. ${ }^{[50]}$ The presence of various nonstoichiometric iron carbides and their transition was also predicted using first-principles calculations, and was associated with the possible stabilization by coherency strains with the surrounding iron-rich matrix. ${ }^{[51]}$ Due to the difference in the processing 


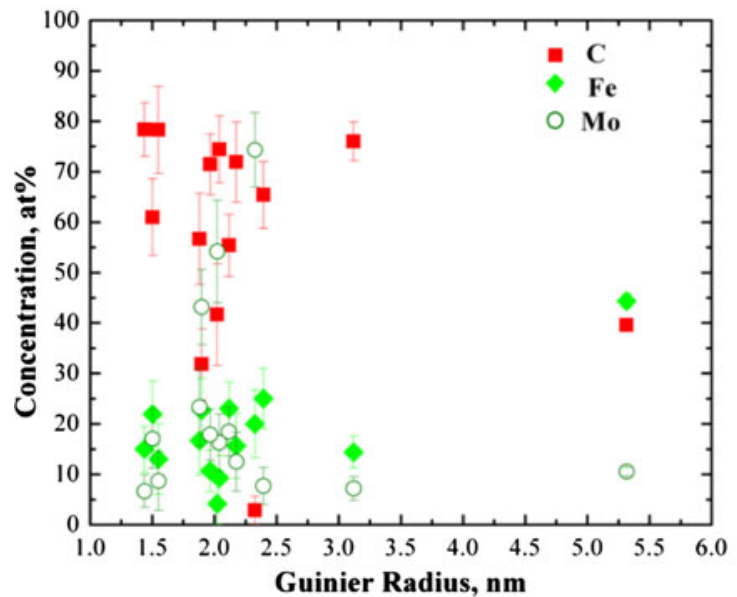

(a)

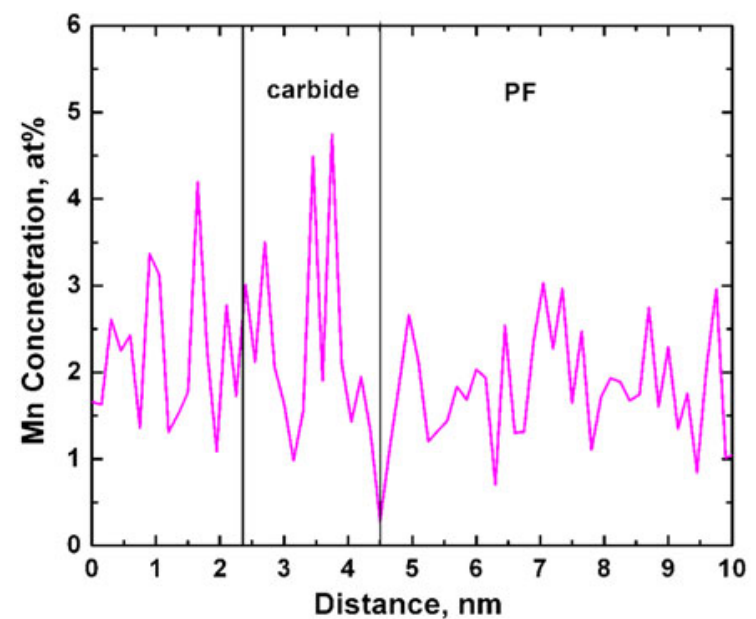

(c)

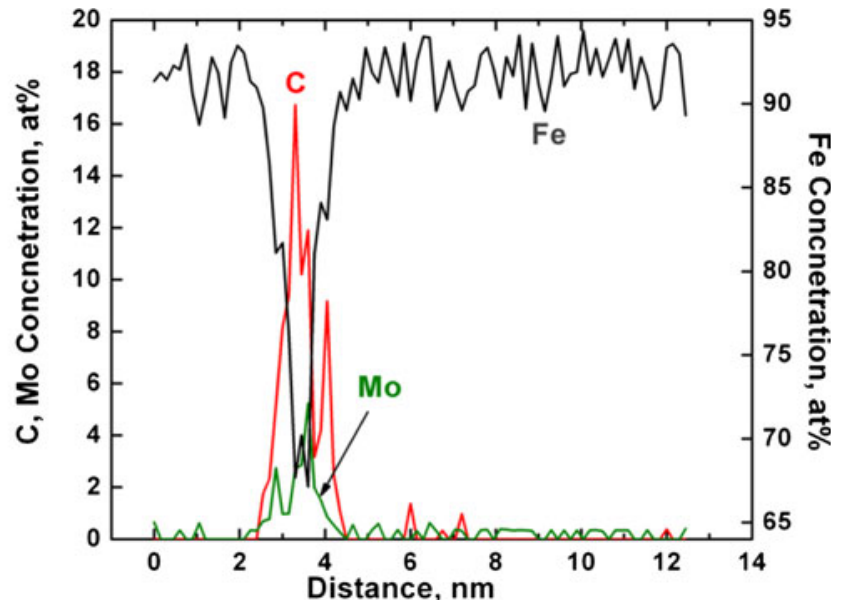

(b)

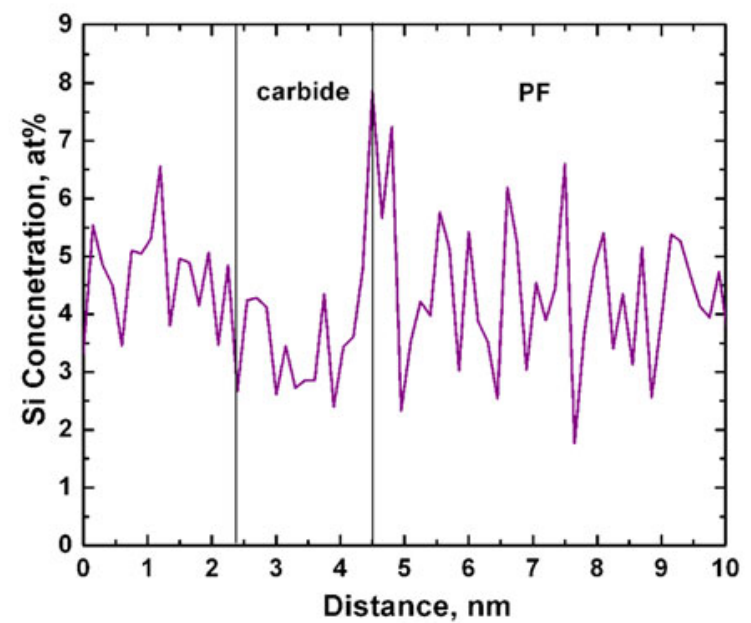

(d)

Fig. 7-(a) Evolution of cluster/fine precipitate composition with size in the polygonal ferrite of steel 2; and (b) Fe, C, and Mo, (c) Mn, and (d) $\mathrm{Si}$ concentration profiles across a representative fine Fe-Mo-C carbide.

schedule and the higher Mo content, a larger variety of carbides was present in steel 2 compared with steel 1 . In addition to the formation of clusters and precipitates in the BF, a significant number was detected in the PF of steel 2. The summary of these carbide compositions is given in Figure 7(a), and the representative concentration profiles across a carbide containing $\sim 70$ at. pct Fe, 6 at. pct Mo, and 20 at. pct $\mathrm{C}$ with traces of $\mathrm{Mn}$ are shown in Figures 7(b) through (d). A Si buildup is also visible at one side of the carbide/matrix interface (Figure 7(d)). This is consistent with the previous report on Si buildup at the cementite/ferrite interface observed by Chang and Smith using field ion microscopy ${ }^{[52]}$ and supports the theory proposed by Owen ${ }^{[53]}$ on suppression of cementite formation in Si-containing steels due to the rejection of low soluble Si from cementite and its buildup in front of the moving cementite/ferrite interface. For cementite formation to take place, diffusion of $\mathrm{Si}$ atoms from the interface into the ferrite matrix is required. However, the activation energy for $\mathrm{Si}$ diffusion in bcc iron is within the range of 227 to $233 \mathrm{~kJ} / \mathrm{mol},{ }^{[54,55]}$ which is comparable with the activation energy of $229 \mathrm{~kJ} / \mathrm{mol}$ for cementite formation. ${ }^{[53]}$ The composition of clusters/fine precipitates in the PF was as follows: 60 to 80 at. pct $\mathrm{C}$-rich $\mathrm{C}-\mathrm{Mo}-\mathrm{Fe}$ clusters, precipitates of $(\mathrm{Mo}, \mathrm{Fe})_{2} \mathrm{C}$ and possibly $(\mathrm{Fe}, \mathrm{Mo})_{7} \mathrm{C}_{3}$. According to the THERMOCALC calculations, $\mathrm{M}_{6} \mathrm{C}$-type carbides could form during a holding time at $923 \mathrm{~K}\left(650{ }^{\circ} \mathrm{C}\right)$, whereas formation of $\mathrm{M}_{7} \mathrm{C}_{3}$ takes place below $673 \mathrm{~K}\left(400{ }^{\circ} \mathrm{C}\right)$, e.g., during the isothermal hold temperature of $573 \mathrm{~K}$ $\left(300{ }^{\circ} \mathrm{C}\right)$.

\section{Comparison of the mechanical behavior} of nanobainitic steels

As was addressed previously, steel 1 displayed very high strength and low elongation, whereas steel 2 had a much better combination of strength and ductility. The main difference in the microstructures of both steels is the presence of $\sim 20$ pct of PF in steel 2, which being a softer phase contributes to the load transfer between the phases and makes the steel more ductile. However, this still would not account for such a difference in the elongation for both steels. As atom probe data revealed, the carbon content in the RA of steel 1 was more than 

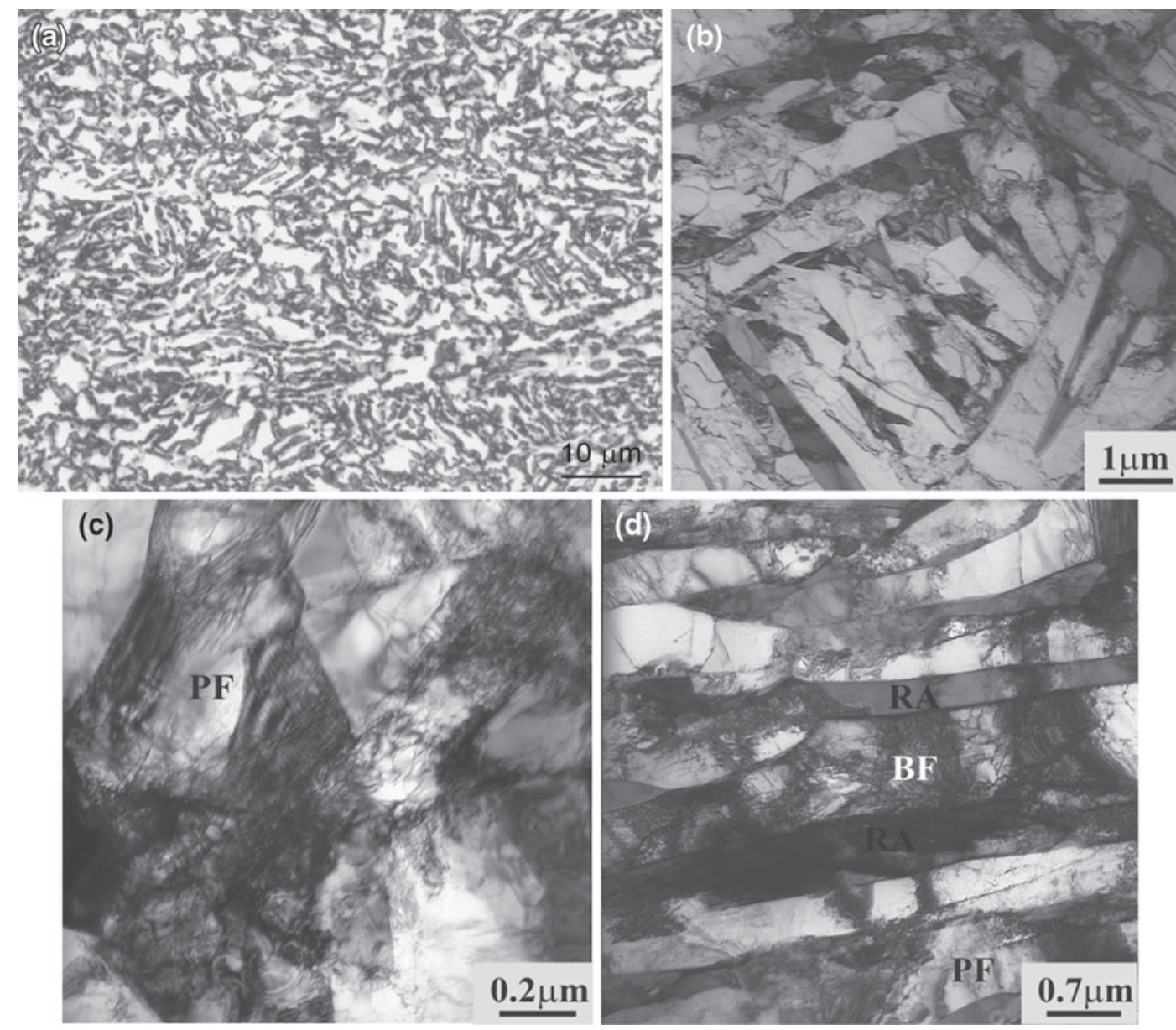

Fig. 8- (a) Optical and (b) through (d) bright-field TEM micrographs showing the microstructure of TRIP steel 3. PF is polygonal ferrite, BF is bainitic ferrite, and RA is retained austenite.

double that in the RA of steel 2. In addition, the majority of the RA layers were coarser in steel 2 compared to the ones in steel 1 . It is well known that the RA is subject to both chemical and mechanical stabilization. ${ }^{[27,56,57]}$ In order for transformation to martensite to take place under the load, the size of the RA should be sufficient for the martensite nuclei to form and its carbon content should be an intermediate one. If the carbon content is too low, then the RA will transform very quickly on initial loading and will not contribute significantly to the work hardening and ability of the steel to withstand the load. However, if the carbon level is too high, then transformation to martensite will not happen at all. As we could see from the micro- and nanoscale analysis, both mechanical and chemical stabilization of the RA in steel 1 could take place to a larger extent than those in steel 2. XRD data have also confirmed that whereas only $\sim 30$ pct of the RA remained untransformed in steel 2 after tensile testing, nearly 50 pct of RA was still present in steel 1 . These findings explain the observed low ductility in steel 1 and support the earlier suggestion on the strong effect of chemical composition of the RA in nanostructured bainitic steels on their ductility. ${ }^{[58]}$

\section{B. TRIP Steel 3}

1. Micro- and nanoscale analysis

In the as-received condition, the microstructure of the steel consists of $\sim 30 \pm 3$ pct polygonal ferrite, $\sim 56 \pm 3$ pct bainite, $\sim 10 \pm 3$ pct RA with an average carbon content of $1.21 \pm 0.04 \mathrm{wt}$ pct, and the remaining martensite (Figure 8(a)). The average polygonal ferrite grain size was $3 \pm 1.5 \mu \mathrm{m}$. Based on XRD data, after $\mathrm{PS} / \mathrm{BH}$ treatment, the volume fraction of RA was reduced from $\sim 10 \mathrm{pct}$ in the as-received condition to $\sim 8$ pct in $\mathrm{PS} / \mathrm{BH}$ state. In addition, the $\mathrm{PS} / \mathrm{BH}$ treatment leads to an increase in average carbon content of RA to $1.28 \pm 0.04 \mathrm{wt}$ pct. From TEM micrographs, it is clear that bainite colonies are present in the microstructure (Figure 8(b)) with carbide-free morphologies of granular bainite (Figure 8(c)) and dominant arrangements of parallel BF laths with interlayers of RA (Figure 8(d)).

APT analysis revealed the presence of carbon-rich clusters, fine iron carbides, and carbon segregation at dislocations in polygonal ferrite of as-received steel (Figure 9). An example of a rod-like Cottrell atmosphere is shown from two perpendicular directions in Figures 9(c) and (d). A concentration profile across the 


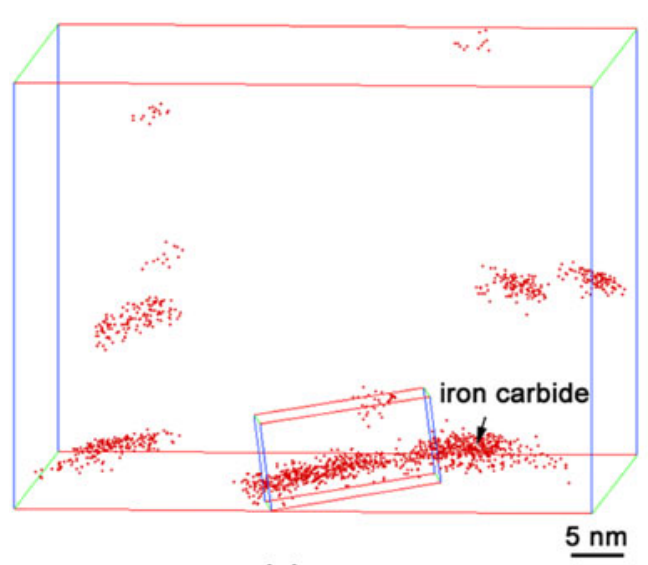

(a)

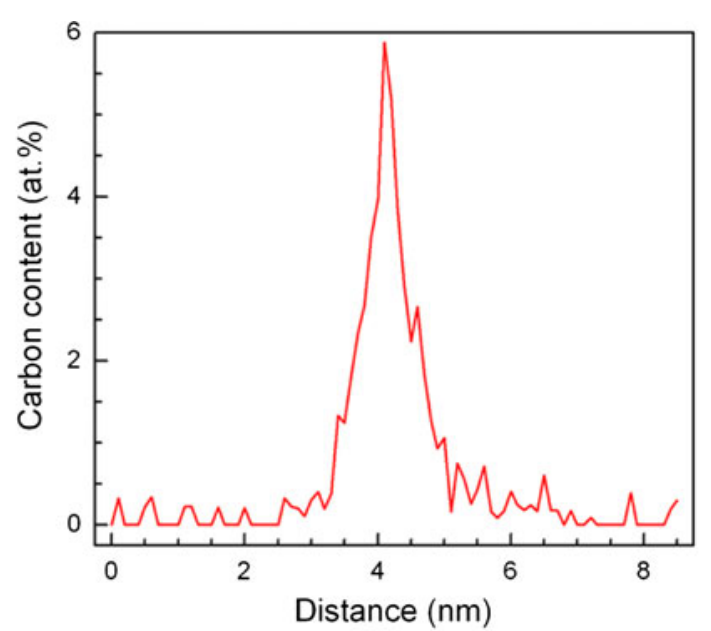

(b)

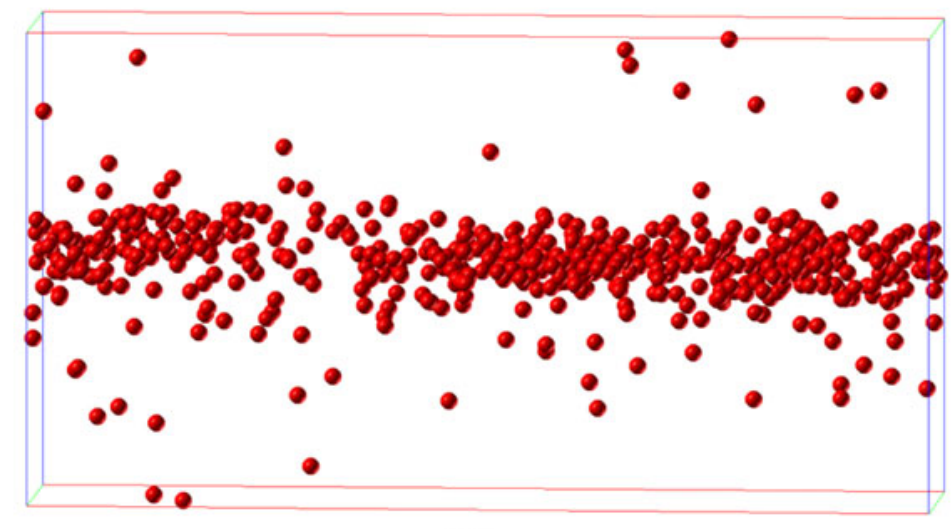

(c)

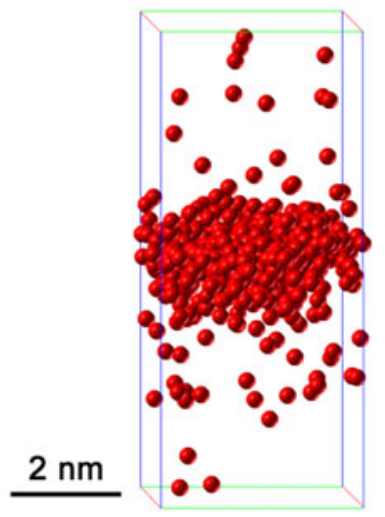

(d)

Fig. 9-(a) C-rich clusters in the as-received steel. All matrix atoms were removed with the maximum separation envelope method with $d_{\max }=1 \mathrm{~nm}$. (b) Concentration profile of $\mathrm{C}$ across the selected Cottrell atmosphere, and $(c)$ and $(d)$ corresponding $\mathrm{C}$ atom map of the selected Cottrell atmosphere showing the shape of the atmosphere from two perpendicular directions.

atmosphere indicates that the $\mathrm{C}$ content at its center is about 6 at. pct (Figure 9(b)). Analysis has shown that the concentration of carbon at dislocations was in the 5 to 9 at. pct range. In addition, the majority of clusters were detected within the PF and BF crystals; however, iron carbides were associated with Cottrell atmospheres. After PS/BH treatment, the APT showed a significant increase in the number of observed Cottrell atmospheres at dislocations both in PF and BF (Figure 10). There was also a significant spread in the carbon concentrations within the atmospheres ranging from 3 to 14 at. pct. A representative concentration profile of such atmosphere with high carbon content is given in Figure 10(c). Representative atmosphere with low segregation of carbon is denoted by CA2 in Figure 10(a). From 4 at. pct $\mathrm{C}$ iso-concentration surfaces (Figure 10(b)), it is also clear that low and non-uniform carbon distribute in such an atmosphere. Formation of iron carbides was also evident on the high carbon atmospheres (Figure 10(a)). Analysis of the carbide composition revealed that the carbon content was $\sim 21$ at. pct, which is slightly lower than 25 at. pct carbon content in $\mathrm{Fe}_{3} \mathrm{C}$. This could be explained, as mentioned previously, by carbon vacancy formation in cementite. ${ }^{[50]}$ Evolution of cluster/fine precipitate composition as a function of size for both studied conditions is shown in Figure 11. As seen from Figure 11, the C content in clusters has a similar dependence on cluster size when the sizes are smaller than $3 \mathrm{~nm}$ in both conditions. In these fine clusters, the $\mathrm{C}$ content varies from $\sim 80$ to 95 at. pct, which is close to the composition of $\mathrm{FeC}_{8}$. However, the steel in the as-received condition contains transition carbides of 3- to 4- nm size with 35 to 65 at. pct $\mathrm{C}$ content, whereas no transition carbides were observed in the steel after PS/BH. When the carbide size is above $r_{\mathrm{G}}=11 \mathrm{~nm}$, its composition is close to that of $\mathrm{Fe}_{3} \mathrm{C}$ (Figure 11). These coarse carbides also contain traces of $\mathrm{Mn}$. Slightly coarser $\mathrm{Fe}_{3} \mathrm{C}$ carbides were present after $\mathrm{PS} / \mathrm{BH}$ treatment (Figure 11(b)). Similar trends in cluster/fine carbide compositions were previously reported for bake-hardened thermomechanically processed TRIP steels ${ }^{[15,21]}$ and DP steels. ${ }^{[10]}$

\section{Mechanical behavior}

Figure 12 shows the engineering stress-strain curves of the steel in both as-received and $\mathrm{PS} / \mathrm{BH}$ states. The steel in both conditions exhibits a good combination of 

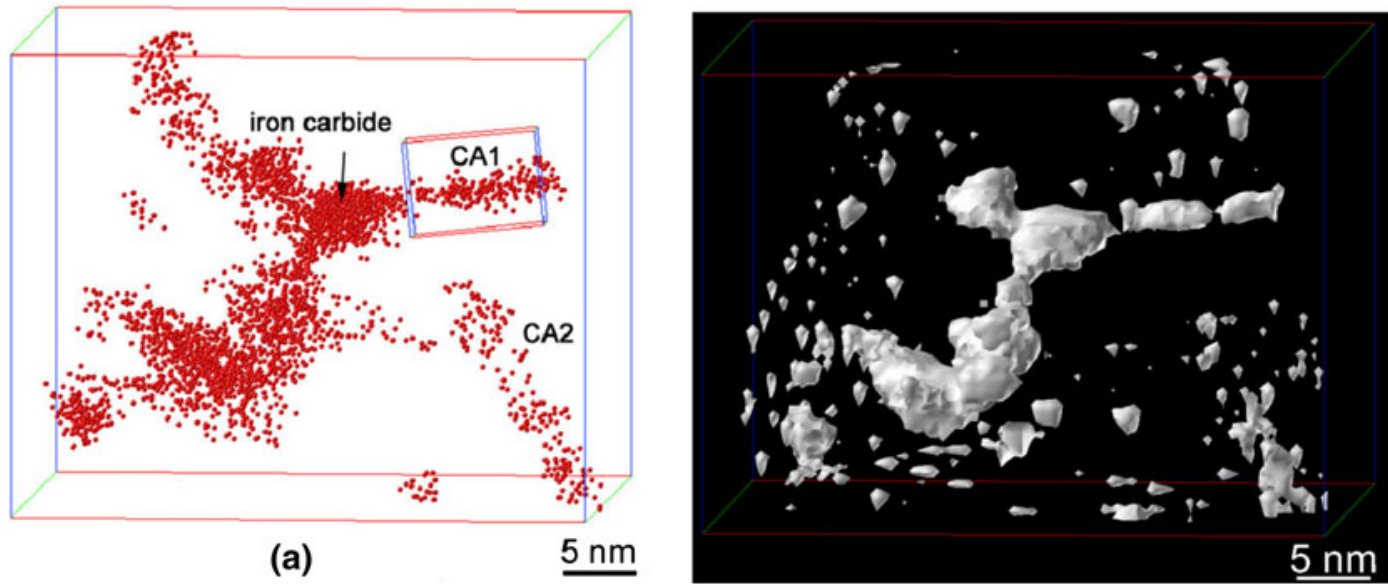

(b)

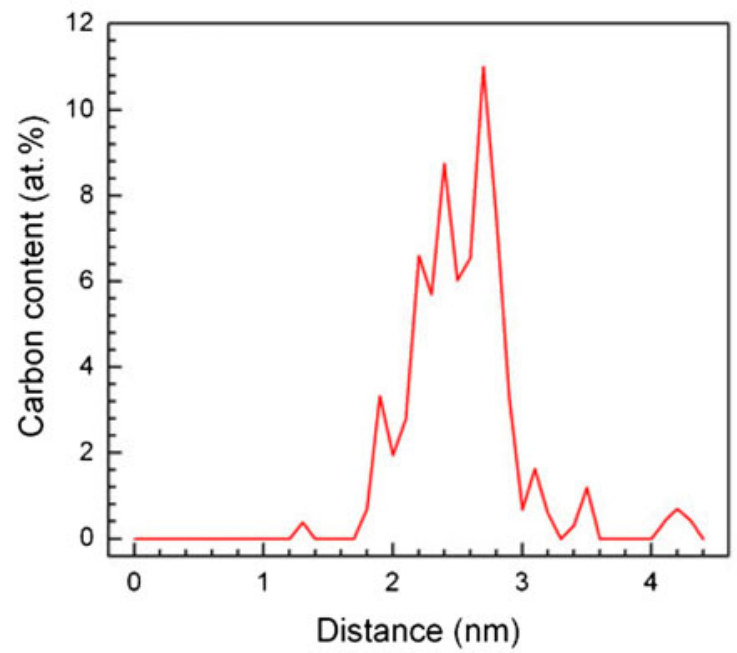

(c)

Fig. 10-(a) C-rich clusters and (b) corresponding 4 pct C iso-concentration surface in a bainite matrix in the steel after PS/BH treatment and (c) concentration profile of $\mathrm{C}$ across the selected Cottrell atmosphere. All matrix atoms were removed with the maximum separation method with $d_{\max }=1 \mathrm{~nm}$. CA1 is representative pre-existing Cottrell atmosphere with iron carbides, and CA2 is an example of newly formed Cottrell atmosphere after PS/BH treatment. Note the difference in C concentration within CA1 and CA2.

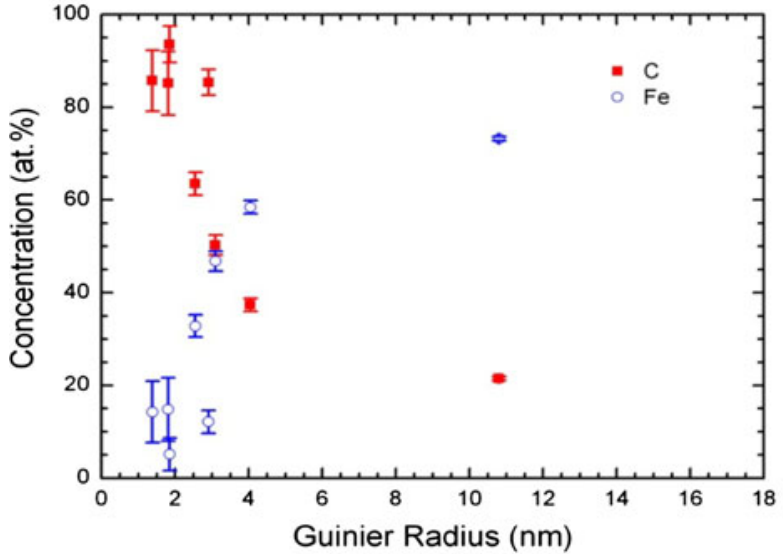

(a)

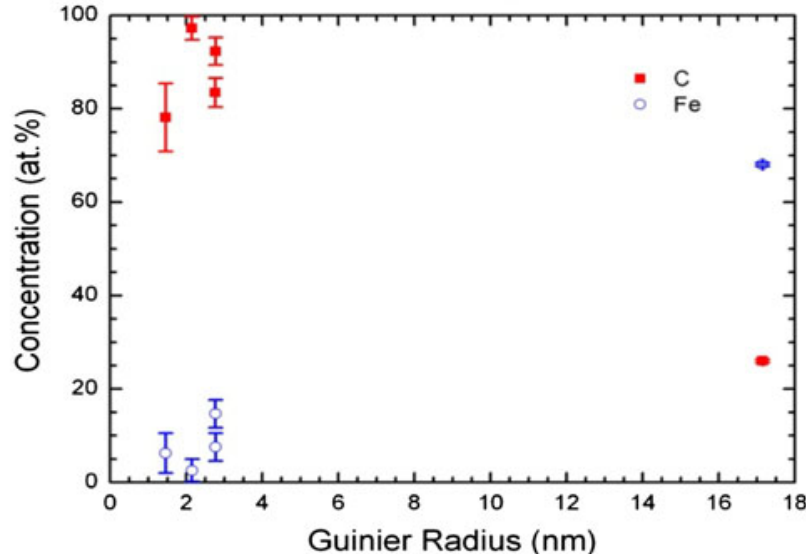

(b)

Fig. 11-Compositions of the major alloying elements of the clusters/precipitates in $(a)$ the as-received steel and $(b)$ after PS/BH treatment as a function of their Guinier radii. The error bars are based on the number of atoms in each cluster. 


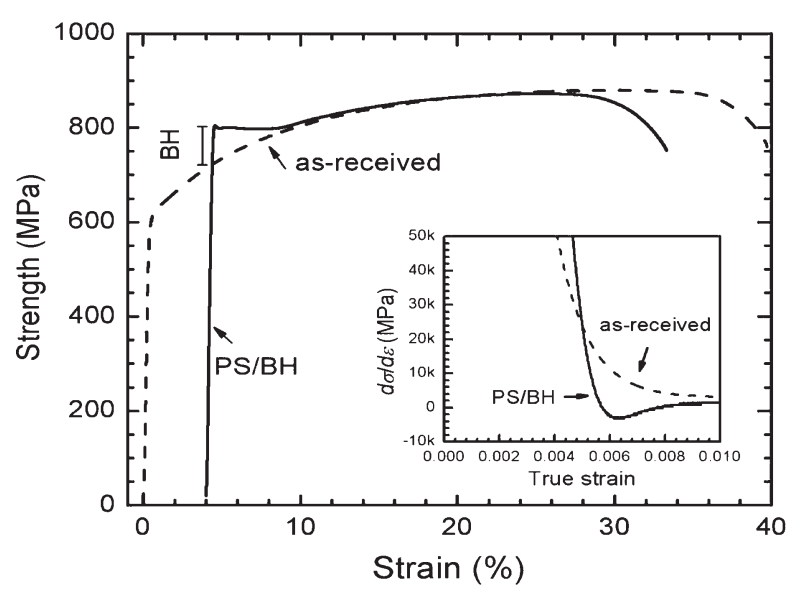

Fig. 12-Uniaxial tensile stress-strain curves and strain hardening rate (inset) of steel 3 after different processing.

strength and ductility. In the as-received condition, the steel shows a continuous yielding behavior. The strain hardening rate decreases in a continuous exponential (inset). However, a distinct yield point phenomenon is observed in the steel after PS/BH treatment. After yield point elongation, the flow stress starts to increase until necking occurred. The strain-hardening rate of the steel after $\mathrm{PS} / \mathrm{BH}$ treatment decreases sharply to negative values and then starts to increase at around 0.65 pct true strain. The obtained mechanical properties in both conditions are summarized in Table II. The PS/BH treatment leads to a significant increment in yield strength of $\sim 200 \mathrm{MPa}$ and a noticeable bake hardening response of $\sim 82 \mathrm{MPa}$.

It is noted that the PS/BH treatment changed the yielding behavior of TRIP steel from continuous yielding in the as-received condition to discontinuous yielding in the PS/BH state (Figure 12 inset). The yielding point on stress-strain curves generally occurs as a result of the dislocations unlocking from Cottrell atmospheres by a high stress or for the case of a strong pinning by fine precipitates, by creating new dislocations. Though a number of Cottrell atmospheres exist in the studied steel in both as-received and $\mathrm{PS} / \mathrm{BH}$ states, these Cottrell atmospheres may play different roles in the yielding phenomenon. A relatively low quantity of the Cottrell atmospheres could not play a leading role in yielding in the as-received condition. In addition, iron carbides were observed on Cottrell atmospheres present in the as-received condition (Figure 9), which results in strong locking of dislocations and prevents their unlocking under tensile stress. In contrast, there is distinct evidence of a large number of Cottrell atmospheres in the steel after PS/BH treatment (Figure 10), both pre-existing with high carbon concentration and iron carbides (CA1 in Figure 10(a)) and newly formed (CA2 in Figure 10(a)). It could be speculated that a high number of freshly formed dislocations during prestraining were decorated with carbon atmospheres during bake hardening. This weak locking of dislocations by Cottrell atmospheres plays an overwhelming role in the yielding phenomenon after $\mathrm{PS} / \mathrm{BH}$ treatment. The presence of a local minimum on the strain-hardening rate curve
(Figure 12 inset) proves that the dislocation unlocking process is responsible for the observed yield point drop in this steel, contrary to the mechanism of the formation of new dislocations in the TRIP steels with a high volume fraction of polygonal ferrite. ${ }^{[17,34]}$

\section{CONCLUSIONS}

Application of APT to study nanobainitic steels allowed us to elucidate the alloying element redistribution between phases and gain insight into the mechanism of phase transformations.

Better strength-ductility balance was achieved in Mo steel containing polygonal ferrite in addition to nanobainite, which is associated with (1) less stability of the RA due to lower $\mathrm{C}$ content contributing to the TRIP effect and (2) additional solid solution and cluster/precipitation strengthening due to alloying with Mo.

A yield point phenomenon is observed in intercritically annealed C-Mn-Si TRIP steel after prestraining/ bake hardening treatment. It is suggested that dislocation unlocking from the weak, newly formed during bake hardening Cottrell atmospheres is responsible for this.

\section{ACKNOWLEDGMENTS}

The authors acknowledge the technical support for atom probe studies by the Monash Centre for Electron Microscopy and the Electron Microscopy Unit, University of Sydney. The authors are also grateful to Professor S. Babu, Ohio University, for THERMOCALC calculations.

\section{REFERENCES}

1. M.K. Miller: in Handbook of Microscopy for Nanotechnology, Nan Yao and Z.L. Wang, eds., Kluwer Academic Press, New York, NY, 2005, pp. 227-47.

2. M.K. Miller: Atom Probe Tomography, Kluwer, Academic/Plenum Press, New York, NY, 2000, pp. 28-197.

3. T.F. Kelly and M.K. Miller: Atom Probe Tomogr., Rev. Sci. Instrum., 2007, vol. 78, pp. 031101-031101-20.

4. M.H. Hong, W.T. Reynolds, T. Tarui, and K. Hono: Metall. Mater. Trans. A, 1999, vol. 30A, pp. 717-27.

5. M. Peet, S.S. Babu, and M.K. Miller: Scripta Mater., 2004, vol. 50, pp. $1277-81$.

6. F.G. Caballero and H.K.D.H. Bhadeshia: Curr. Opin. Solid State Mater. Sci., 2004, vol. 8, pp. 251-57.

7. E.V. Pereloma, I.B. Timokhina, M.K. Miller, and P.D. Hodgson: Acta Mater., 2007, vol. 55, pp. 2587-98.

8. F.G. Caballero, M.K. Miller, S.S. Babu, and C. Garcia-Mateo: Acta Mater., 2007, vol. 55, pp. 381-90.

9. F.G. Caballero, C. Garcia-Mateo, M.J. Santofimia, M.K. Miller, and C. García de Andrés: Acta Mater., 2009, vol. 57, pp. 8-17.

10. I.B. Timokhina, E.V. Pereloma, S.P. Ringer, R.K. Zheng, and P.D. Hodgson: ISIJ Int., 2010, vol. 50 (4), pp. 574-82.

11. J. Wilde, A. Cerezo, and G.D.W. Smith: Scripta Mater., 2000, vol. 43, pp. 39-48.

12. E. Cadel, A. Fraczkiewicz, and D. Blavette: Mater. Sci. Eng. A, 2001, vols. A309-A310, pp. 32-37.

13. M.K. Miller, P. Pareige, and M.G. Burke: Mater. Charact., 2000, vol. 44, pp. $235-54$. 
14. E.V. Pereloma, I.B. Timokhina, J.J. Jonas, and M.K. Miller: Acta Mater., 2006, vol. 54, pp. 4539-51.

15. E.V. Pereloma, K.F. Russell, M.K. Miller, and I.B. Timokhina: Scripta Mater., 2008, vol. 58, pp. 1078-81.

16. E.V. Pereloma, A.A. Gazder, J.J. Jonas, M.K. Miller, and C.H.J Davies: ISIJ Int., 2008, vol. 48, pp. 1443-50.

17. L.C. Zhang, I.B. Timokhina, A. La Fontaine, S.P. Ringer, P.D. Hodgson, and E.V. Pereloma: La Metall. Italiana, 2009, vol. 101 (6), pp. 49-55.

18. F.G. Caballero, M.K. Miller, C. Garcia-Mateo, C. Capdevila, and S.S. Babu: Acta Mater., 2008, vol. 56, pp. 188-99.

19. I.B. Timokhina, P.D. Hodgson, H. Beladi, and E.V. Pereloma: La Metall. Italiana, 2009, vol. 101 (11-12), pp. 43-48.

20. M.K. Miller, A.A. Chernobaeva, Y.I. Shtrombakh, K.F. Russell, R.K. Nanstad, D.Y. Erak, and O.O. Zabusov: J. Nucl. Mater., 2009, vol. 385, pp. 615-22.

21. E.V. Pereloma, M.K. Miller, and I.B. Timokhina: Metall Mater. Trans. A, 2008, vol. 39A, pp. 3210-16.

22. E.V. Pereloma, I.B. Timokhina, K.F. Russell, and M.K. Miller: Scripta Mater., 2006, vol. 54, pp. 471-76.

23. E.V. Pereloma, R.A. Stohr, M.K. Miller, and S.P. Ringer: Metall. Mater. Trans. A, 2009, vol. 40A, pp. 3069-75.

24. C. Garcia-Mateo, F.G. Caballero, and H.K.D.H. Bhadeshia: ISIJ Int., 2003, vol. 43, pp. 1821-25.

25. H.K.D.H. Bhadeshia: Mater. Sci. Technol., 2005, vol. 21, pp. $1293-1302$

26. F.G. Caballero, M.K. Miller, and C. Garcia-Mateo: Acta Mater. 2010, vol. 58, pp. 2338-43.

27. I.B. Timokhina, P.D. Hodgson, and E.V. Pereloma: Metall. Mater. Trans. A, 2004, vol. 35A, pp. 2331-41.

28. P.J Jacques, J. Ladrière, and F. Delanny: Metall. Mater. Trans. A, 2001, vol. 32A, pp. 2759-68.

29. I.B. Timokhina, H. Belladi, X. Xiong, E.V. Pereloma, and P.D. Hodgson: Mater. Sci. Forum, 2010, vols. 654-656, pp. 102-05.

30. B.C. De Cooman: Curr. Opin. Solid State Mater. Sci., 2004, vol. 8 , pp. 285-303.

31. D.V. Edmonds, K. He, F.C. Rizzo, B.C. De Cooman, D.K Matlock, and J.G. Speer: Mater. Sci. Eng. A, 2006, vols. 438-440, pp. 25-34.

32. L.J. Baker, S.R. Daniel, and J.D. Parker: Mater. Sci. Technol., 2002, vol. 18 , pp. 355-68

33. T. Waterschoot, A.K. De, S. Vadeputte, and B.C. De Cooman: Metall. Mater. Trans. A, 2003, vol. 34A, pp. 781-91.

34. I.B. Timokhina, P.D. Hodgson, and E.V. Pereloma: Metall. Mater. Trans. A, 2007, vol. 38A, pp. 2442-54.

35. A.H. Cottrell and B.A. Bilby: Proc. Phys. Soc. A, 1949, vol. 62, pp. 49-62.
36. A.K. De, S. Vandeputte, and B.C. De Cooman: Scripta Mater., 2001, vol. 44, pp. 695-700.

37. I.B. Timokhina, E.V. Pereloma, and P.D. Hodgson: Mater. Sci. Forum, 2007, vols. 539-543, pp. 4315-20.

38. W.C. Jeong: Metall. Mater. Trans. A, 1998, vol. 29A, pp. 463-67.

39. L. Samek, E. De Moor, J.G. Speer, and B.C. De Cooman: Metall Trans. A, 2008, vol. 39A, pp. 2542-54.

40. B.D. Cullity: Elements of X-Ray Diffraction, Addison-Wesley, London, 1978, pp. 411-15.

41. M. Onink, C.M. Brakman, F.D. Tichelaar, E.J. Mittemeijer, S van der Zwaag, J.H. Root, and N.B. Konyer: Scripta Mater. 1993, vol. 29 (8), pp. 1011-16.

42. H.K.D.H. Bhadeshia and D.V. Edmonds: Metall. Trans. A, 1979, vol. 10A, pp. 895-907.

43. J.W. Christian and D.V. Edmonds: Int. Conf. on Phase Transformations in Ferrous Alloys, A.R. Marder and J.I. Goldstein, eds. AIME, Cleveland, OH, 1984, pp. 293-326.

44. H.K.D.H. Bhadeshia and A.R. Waugh: Acta Metall., 1982 , vol. 30, pp. 775-84.

45. H.K.D.H. Bhadeshia: Met. Sci., 1982, vol. 16, pp. 159-65.

46. H.K.D.H. Bhadeshia: Mater. Sci. Technol., 1985, vol. 1, pp. 497 504.

47. I. Stark I, G.D.W. Smith, and H.K.D.H. Bhadeshia: Metall. Trans. A, 1990, vol. 21A, pp. 837-45.

48. J.O. Anderson, T. Helinder, I. Hogland, and B. Sundman: CALPHAD, 2002, vol. 26, pp. 273-312.

49. "Thermotech Fe-Data Thermodynamic Database," Thermotech Ltd./Sente Software Ltd., Guildford, United Kingdom.

50. V.I. Voronin, I.F. Berger, Y.N. Gornostyrev, V.N. Urtsev, A.R. Kuznetsov, and A.V. Shmakov: JETP Lett., 2010, vol. 91 , pp. 143-46.

51. C.M. Fang, M.A. van Huis, and H.W. Zandbergen: Scripta Mater., 2010, vol. 63, pp. 418-21.

52. L. Chang and G.D.W. Smith: J. Phys., 1984, vol. C9 (1), suppl., pp. 397-401.

53. W.S. Owen: Trans. ASM, 1954, vol. 46, pp. 812-29.

54. V. Burachynsky and J.R. Cahoon: Metall. Mater. Trans. A, 1997, vol. 28A, pp. 563-81.

55. E. De Moor, S. Lacroix, L. Samek, J. Penning, and J.G. Speer: Proc. 3rd Int. Conf. on Advanced Structural Steels, Gyeongju, Korea, 2006, pp. 873-78.

56. G. Reisner, E.A. Werner, P. Kerschbaummaur, I. Paps, and F.D Fisher: J. Met., 1997, vol. 49 (9), pp. 62-65.

57. O. Matsumura, Y. Sakuma, and H. Takechi: Scripta Mater., 1987 vol. 21, pp. 1301-06.

58. C. Garcia-Mateo and F.G. Caballero: Mater. Trans., 2005, vol. 46 pp. 1839-46. 